\title{
Scott Joseph Seregny, 1950-2003
}

On 16 June 2003, the Russian studies profession lost Scott J. Seregny, professor of Russian and European history at Indiana University, Indianapolis, and the author and editor of two scholarly books and many articles on the history of Russian education, social history, and the provincial culture of late tsarist Russia. Born on 20 November 1950, Scott was only in his early fifties when his life was cut short after a four-year struggle with cancer.

I first met Scott during the Gorbachev era, in the reading room of the old Tsentral'nyi gosudarstvennyi arkhiv Oktiabr'skoi revoliutsii in Moscow, when the archivists were first allowing foreigners to consult opisi (inventories) and to sit together with Soviet citizens in one main reading room. Scott had just given the main archivist a copy of his first book and observed to me that he might have been able to provide greater detail in some parts of his book if he had previously been granted access to the opisi. That work, Russian Teachers and Peasant Revolution: The Politics of Education in 1905 (Indiana University Press, 1989), revised our notion of rural teachers in revolutionary Russia. Scott challenged the notion that rural teachers were "zemstvo rabbits," that is, that they were devoid of power and even oblivious to the burning questions of the day. And he argued that close scrutiny of rural teachers during the 1905 revolutionary era reveals their dynamic, changing relationship with local communities just as he questioned long-term assumptions about peasant isolation from both national politics and Russian society in general.

These lines of analytical inquiry led Scott into further research on rural intellectuals and provincial educators. Together with Rex Wade, he edited Politics and Society in Provincial Russia: Saratov, 1590-1917 (Ohio State University Press, 1989), a work that attempted to shift the focus of Russian historical analysis away from the traditional centers of St. Petersburg and Moscow. They believed that, at the time, broad studies of the Great Russian regions were conspicuously missing from western historical literature. Saratov became the focus of their study since it contained unusually good collections of source materials, was predominantly Great Russian (76.7 percent of its population prior to 1917), and was a major agricultural producer with a dynamic urban sector.

Scott's more recent research articles focused on the period between World War I (1914) and the February 1917 revolution. He became more interested in the adult education movement (vneshkol'noe obrazovanie), particularly in provincial areas in Russia. In a relatively recent Slavic Review article, "Zemstvos, Peasants, and Citizenship: The Russian Adult Education Movement and World War I" (Slavic Review 59, no. 2 [Summer 2000]: 290-315), Scott examined the new zemstvo field of adult education. He argued that these zemstvo participants were deeply involved in a broader rural enlightenment project and that they saw the war as a unique opportunity to extend their cultural mission in the villages while trying to construct the rudiments of civic identity among the peasantry.

In 1998, our paths crossed in Russia for the last time. I was looking at the provincial newspaper collection of the 1920s and 1930s, and Scott was working in the zemstvo archive in the Saltykov-Shchedrin Library in St. Petersburg. His excitement about his new project was contagious, and it is sad that his promising research was cut short.

In addition to his scholarly contributions, Scott will also be remembered for his unselfish generosity in helping younger colleagues- he graciously read their work and offered advice both at the Midwest Russian History Workshops and at the national conventions of the AAASS. His friends and colleagues will miss this generosity, as well as his gregarious nature, affable personality, and booming laughter that could fill a room. Scott will be sorely missed by all who knew him. 